\title{
Czy wykonywać badanie PSA w celu wykrycia raka stercza?
}

\author{
Radzisław Kordek
}

PSA test for detection of prostate cancer: should we perform it?

\begin{abstract}
Skrining PSA w celu wykrywania i leczenia raka stercza od wielu lat budzi liczne kontrowersje. Dyskutowana jest czułość i swoistość testu, efekt populacyjny, rachunek zysków i strat. Wątpliwości budzi już sam test PSA, niebędącym wystarczająco czułym i swoistym do wykrywania raka stercza.

Opublikowane ostatnio wyniki badań randomizowanych (ERSPC, PLCO) wyjaśniły nieco sytuację. Stwierdzono umiarkowane obniżenie umieralności na raka stercza w grupie poddanej skriningowi PSA, lecz nie towarzyszyło temu obniżenie umieralności ogólnej. Natomiast towarzyszyły temu znaczne koszty w postaci powikłań po leczeniu, obejmujące także poważne zagrożenia życia i zgony. W innym badaniu (PIVOT) stwierdzono, że prostatektomie nie zmniejszają umieralności w tej grupie, a efekt korzystny obserwowano tylko u chorych z wysokim PSA (ponad $10 \mathrm{ng} / \mathrm{ml}$ ). Na podstawie tych doniesień wiele autorytetów i organizacji medycznych zaleca zaniechanie wykonywania testu PSA lub ograniczanie tego badania dla mężczyzn wykazujących taką chęć, ale dopiero po zapoznaniu się z rachunkiem potencjalnych zysków i strat.

Podejmowane są próby zmniejszenia liczby niepotrzebnych interwencji medycznych i liczby powikłań, między innymi w postaci rzadszego badania PSA i stosowania kalkulatora ryzyka. Nie ma jednak wiarygodnych badań wykazujących wpływ tych działań na umieralność związaną z rakiem, umieralność ogólną i liczbę zjawisk niepożądanych.
\end{abstract}

PSA screening for the detection and treatment of prostate cancer raises controversies from many years. There is much discussions concerning the sensitivity and specificity of the test, the population-based effect and profit and loss account. Recently published results of randomized trials (ERSPC, PLCO) clarified the situation somewhat. It was a modest reduction in mortality from prostate cancer in the screened group treated with PSA, but this was not accompanied by the reduction in overall mortality. However, this was accompanied by significant costs in terms of complications after treatment, involving a serious threat to the life and deaths. In another study (PIVOT), prostatectomy dis not reduce mortality in the whole group, but a beneficial effect was observed only in patients with high PSA (over $10 \mathrm{ng} / \mathrm{ml}$ ).

Based on these reports, many authorities and medical scientific organizations recommend not to use the PSA test at all, or to limit it for men expressing clear preference, but only after presentation of the account of potential gains and losses. Attempts are being made to reduce the number of unnecessary medical intervention and the number of complications, such as less frequent testing and application of the PSA and the risk calculator. However, we have no reliable studies showing the impact of these changes on cancer-specific mortality, all-cause mortality and the number of adverse events.

NOWOTWORY Journal of Oncology 2013; 63, 6: 481-485

Słowa kluczowe: PSA, skrining, rak stercza, rak prostaty

Key words: PSA, screening, prostate cancer

Zakład Patologii Katedry Onkologii, Uniwersytet Medyczny w Lodzi

Praca finansowana ze środków na działalność statutową Zakładu Patologii 503/1-034-03/503-01

Wystąpienie podczas I Konferencji Naukowej czasopisma Nowotwory „Debaty onkologiczne” 5-6 kwietnia 2013 roku 


\section{Wstęp}

Problematyka masowych badań przesiewowych stanowi przedmiot wielu badań i dyskusji. Mimo że wiele badań diagnostycznych może wykrywać nowotwory, niewiele takich badań jest zalecanych jako masowy skrining u osób niewykazujących objawów. Warunkiem stosowania takich testów jest wykazanie ewidentnej korzyści w postaci obniżenia umieralności oraz analiza zysków wobec strat w postaci powikłań medycznych i psychicznych oraz jakości życia. Nie bez znaczenia są też analizy ekonomiczne i koszt uratowanego roku życia.

Trwają dyskusje, który wskaźnik umieralności powinien być brany pod uwagę. Tradycyjnie, zwracano uwagę przede wszystkim na obniżenie umieralności na dany nowotwór, jednak badania wykazujące obniżenie tego wskaźnika, przy braku wpływu na ogólną umieralność, uświadomiły nam, że zysk w postaci redukcji liczby zgonów na nowotwór może być zrównoważony zwiększoną umieralnością zależną od stosowanych procedur medycznych. Medycyna nie tylko pomaga, często szkodzi - nie można o tym zapominać.

Najmniej kontrowersyjnym skriningiem jest cytologia szyjki macicy. Mimo że nie badano jego efektywności w badaniach randomizowanych, obserwowany efekt nie budzi żadnych wątpliwości. Jest to jednak skrining specyficzny, nastawiony nie tylko na wykrywanie wczesnych raków, ale - a może przede wszystkim - na wykrywanie stanów przedrakowych, co w długoletniej obserwacji ma zmniejszyć liczbę naciekających raków szyjki macicy. Trwają dyskusje, jaką populację badać i jak często, co ma uzasadnienie nie tylko medyczne, ale i ekonomiczne. Najlepszy efekt populacyjny uzyskano w Finlandii, gdzie bada się kobiety najrzadziej - co 5 lat.

Podobne zadanie, to jest wykrywanie zmian przedrakowych i raków, mają badania skiningowe w kierunku raka jelita grubego, nastawione nie tylko na wykrywanie raków, ale także gruczolaków, z których rozwija się wiele raków. Zalecany powszechnie test na krew utajoną w kale jest skuteczny w obniżaniu umieralności, jednak stosunkowo mało swoisty i obarczony wadami (konsekwencje wyników fałszywie dodatnich i fałszywie ujemnych, powikłań po kolonoskopii i terapii) [1]. Obecnie coraz więcej danych przemawia na korzyść skriningu opartego na endoskopii, co udowodniono w badaniach randomizowanych dla rektosigmoidoskopii i w badaniach obserwacyjnych dla kolonoskopii, gdzie bardzo duży efekt populacyjny daje nawet jednokrotne badanie.

Trzecim skriningiem powszechnie zalecanym jest mammografia. Mimo silnej pozycji w powszechnym odbiorze, ta metoda budzi szereg wątpliwości. Tym bardziej, że redukcji umieralności na raka piersi nie towarzyszy obniżenie ogólnej umieralności, co jest spowodowane przede wszystkim stosowaną terapią, w tym w przypadkach, które nawet nieleczone w swoim biologicznym przebiegu nie zmieniłyby przeżyć [2-4]. Wydaje się, że ten temat będzie jeszcze powracał, chociaż utrwalona świadomość społeczna i lobby tego skriningu mogą utrudniać rzeczową dyskusję.

Badaniem, które obniża umieralność na nowotwór, a nie jest zalecane, jest tomografia poszukująca raka płuca. Nieznaczny zysk jest tam okupiony licznymi stratami w postaci nadrozpoznawalności oraz powikłań medycznych i społeczno-psychicznych [5].

Prowadzono badania nad skriningami w celu wykrywania wielu innych nowotworów (m.in. raka żołądka, jajnika, nerki, guzów u dzieci), jednak nie wykazano wystarczającej korzyści w postaci obniżenia umieralności na te nowotwory.

Skrining PSA w celu wykrywania i leczenia raka stercza od wielu lat budzi liczne kontrowersje. Dyskutowana jest czułość i swoistość testu, efekt populacyjny, rachunek zysków i strat. Dyskusje często nie dotyczą faktów, tylko ich interpretacji i opinii, zazwyczaj wynikających z pozycji dyskutantów: urolodzy dość powszechnie zalecają ten test, opinie innych osób są bardziej wstrzemięźliwe, a każdy z dyskutantów ma jakieś argumenty na obronę swoich tez. Przedstawię je poniżej.

\section{Czy test PSA spełnia kryteria testu przesiewowego dla raka stercza?}

Odpowiedź na pytanie, jaka jest czułość i swoistość testu PSA dla raka stercza, nie jest prosta, gdyż zależy od przyjętej metody weryfikacji. Jeżeli przyjmiemy, że weryfikacją jest dodatnia biopsja (czyli zawierająca raka), to trzeba zadać pytanie, jaka biopsja, ile bioptatów, z jakich miejsc itp. Jednak nawet pobieranie bardzo licznych bioptatów nie daje pewności, że pacjent nie ma raka.

W jednej z wielu prac analizujących częstość raka stercza podczas autopsji wykazano, że u mężczyzn poniżej 50 roku życia wskaźnik ten wynosi 0,5\%, Ale w grupie 50-59 wynosi aż 23\%, dla 60-69 jest to 35\%, a dla mężczyzn powyżej 70 roku życia - 46\% [6]. Jest to zatem choroba powszechna. W grupie wiekowej poddawanej skriningowi PSA (55-69) częstość raka stercza podczas autopsji wynosi około 30\%, podczas gdy umiera z tego powodu tylko $2 \%$ mężczyzn.

$W$ jednym $z$ randomizowanych badań dotyczących skriningu PSA [7] wykazano, że na 100 mężczyzn w wieku 55-69 uczestniczących w skriningu PSA dodatni test miało 17 z nich, u 14 wykonano biopsję a u 6 z nich znaleziono raka. U 3 innych rozpoznano raka poza programem skriningowym. Zatem u 9\% rozpoznano raka stercza. Porównajmy to z liczbą 30 wynikającą z badań autopsyjnych. Wynika z tych liczb, że u wielu mężczyzn uczestniczących w skriningu nie rozpoznano raka, i że są to przypadki zarówno z podwyższonym stężeniem PSA, jak i z niskim, gdyż także u wielu mężczyzn z PSA poniżej $4 \mathrm{ng} / \mathrm{ml}$ występuje rak stercza, a ten punkt odcięcia przyjęto całkowicie arbitralnie.

Wielokrotnie badano częstość raka stercza w biopsjach u mężczyzn z PSA poniżej 4 ng/ml [8, 9]. Dla PSA w przedziale 
poniżej 0,5 ng/ml raka stercza rozpoznano u 7\%, a agresywnego raka stercza - u 1\%.W przedziale $0,6-1,0 \mathrm{ng} / \mathrm{ml}$ było to odpowiednio $10 \%$ i $1 \%$, w przedziale $1,1-2,0 \mathrm{ng} / \mathrm{ml}$ — odpowiednio $17 \%$ i $2 \%$, w przedziale $2,1-3,0 \mathrm{ng} / \mathrm{ml}-24 \%$ i 5\%, a w przedziale 3,1-4,0 ng/ml - 27\% i 7\%. Warto zwrócić uwagę, że odsetki dla przedziałów $2-4 \mathrm{ng} / \mathrm{ml}$ są podobne do odsetków uzyskiwanych powyżej $4 \mathrm{ng} / \mathrm{ml}$ !

Jak wynika z powyższych danych, trudno przyjąć jakieś stężenie odpowiednio czułe i swoiste dla raka stercza, a ocena tych parametrów jest utrudniona z powodu niskiej czułości biopsji dla szacowanego z autopsji raka stercza. Nie ma zatem wystarczających dowodów na uznanie wystarczającej czułości i swoistości testu PSA dla wykrywania raka stercza.

\section{PSA i rak stercza — dane epidemiologiczne i wyniki badań}

Wpływ skriningu opartego na PSA na umieralność jest przedmiotem licznych badań i dyskusji. Dane epidemiologiczne z wielu krajów wskazują na wyraźne obniżenie umieralności na raka stercza, co zaobserwowano m.in. w Anglii, Stanach Zjednoczonych, Austrii i Francji [10, 11]. Tendencje te są tłumaczone powszechnością badań PSA.

Wprowadzenie skriningu w Tyrolu zaowocowało obniżeniem umieralności na raka stercza o 33\% w porównaniu $z$ resztą Austrii [12]. Były to jednak badania nierandomizowane. Podobne wyniki uzyskano w badaniu w Kanadzie [13].

Jednak zupełnie przeciwne wyniki uzyskano w badaniu porównującym trendy umieralności w Connecticut i Seattle [14]. W rejonie Seattle prowadzono intensywny skrining, podczas gdy w Connecticut zdarzało się to rzadko. Występowały także duże różnice w stosowanych terapiach. I - zaskakująco - umieralność na raka stercza utrzymywała się w tych dwóch rejonach na podobnym poziomie.

Zatem jeszcze kilka lat temu mieliśmy sytuację, gdzie obserwowane w populacji obniżenie umieralności na raka stercza wiązano z powszechnością badań PSA, jednak badania naukowe dawały wyniki niejednoznaczne i sprzeczne.

Sytuacja zmieniła się w roku 2009, gdy opublikowano wyniki dwóch badań randomizowanych. W badaniu PLCO (The Prostate, Lung, Colorectal and Ovarian Cancer Screening Trial) po 10 latach obserwacji nie wykazano różnic w umieralności na raka stercza pomiędzy grupami poddanymi skriningowi PSA a populacją kontrolną [15]. W komentarzach do tego badania stawiano jednak zarzut, że nie byli wyłączeni panowie z wcześniej wykonywanymi badaniami PSA, wykazano dużą kontaminację grupy kontrolnej i rzadkie stosowanie biopsji przy dodatnim teście.

W 2009 roku opublikowano również pierwsze wyniki z European Randomized Study of Screening for Prostate Cancer (ERSPC), z następną publikacją w 2012 roku, podsumowującą 11-letnią obserwację [7, 16]. W badaniu wzięło udział ponad 162 tysiące osób, gdzie grupie badanej w wieku 55-69 lat oferowano badanie PSA co 4 lata. Wykazano 20\% obniżenie umieralności na raka stercza, a tymczasem, aby uniknąć jednego zgonu na ten nowotwór, trzeba poddać skriningowi 1410 mężczyzn i rozpoznać oraz leczyć 49 raków [7]. Mamy zatem zysk w postaci obniżenia umieralności na nowotwór, ale też znaczny wskaźnik niepotrzebnych terapii.

Publikacja ERSPC z roku 2012 wykazała jednak jeszcze jedną ważna obserwację [16]. Otóż obniżeniu umieralności na raka stercza nie towarzyszy równoległe obniżenie ogólnej liczby zgonów w badaniej grupie. Można zatem założyć, że w badanej grupie istnieją czynniki podwyższające umieralność z innych przyczyn, prawdopodobnie niezwiązane ze skriningiem i terapią raków stercza.

I tak na 1000 mężczyzn w grupie badanej, gdzie uratujemy jednego od śmierci na raka stercza, ponad $30 \mathrm{z}$ nich będzie miało zaburzenia wzwodu lub nietrzymanie moczu. Trzech dozna poważnych powikłań naczyniowo-sercowych związanych z terapią (zawał serca, zator, zakrzepica), a jeden na 3000 - umrze w wyniku powikłań po leczeniu chirurgicznym.

Pod uwagę należy brać nie tylko szkodliwy wpływ procedur medycznych związanych bezpośrednio z diagnostyką i terapią raka stercza, ale także poważne koszty psychologiczne I społeczne. Ważne informacje ujawniło badanie częstości samobójstw u osób poddanych skriningowi PSA, u których wykryto raka [17]. Nawet w grupie mężczyzn z wykrytym rakiem niskiego ryzyka, zazwyczaj nieleczonym i obserwowanym, ryzyko samobójstwa wzrasta czterokrotnie, a w całej grupie z wykrytym rakiem stercza - siedmiokrotnie. Są to nadal małe liczby $(0,45 / 1000$ osób/rok), lecz suma takich różnych zdarzeń może równoważyć zysk w obniżeniu umieralności na raka stercza.

Do grupy kosztów należy także wrzucić rzeczywiste nakłady ekonomiczne. Badanie PSA i następowe postępowanie medyczne jest szacowane w samych USA na przekraczające 3 miliardy dolarów rocznie. Te pieniądze wydane w innych obszarach medycyny mogłyby spowodować mniej kontrowersyjne zyski zdrowotne.

\section{Zalecenia towarzystw i instytucji naukowych}

Najnowsze zalecenia dotyczące badania PSA nawiązują do ostatnich publikacji naukowych, głównie ERSPC i PLCO. W USA i na całym świecie szerokim echem odbiło się stanowisko USPSTF (U.S. Preventive Services Task Force). Jest to grupa wybitnych badaczy, stanowiąca oficjalne ciało doradcze Kongresu USA. W swojej rekomendacji USPSTF nie zaleca w ogóle badania PSA, argumentując to małym potencjalnym zyskiem i znaczącym ryzkiem powikłań [18].

Europejskie Towarzystwo Urologiczne (European Association of Urology) podaje na swojej stronie internetowej: „na podstawie dwóch dużych, randomizowanych badań większość, jeśli nie wszystkie większe towarzystwa urologiczne stwierdza, że szeroki masowy skrining w kierunku raka stercza jest niewłaściwy. Raczej należy zalecać wczesne 
wykrywanie, ale tylko wobec dobrze poinformowanych mężczyzn".

Amerykańskie Towarzystwo Urologiczne (AUA) w swoich najnowszych zaleceniach podaje, że zastosowanie testu PSA w grupie 55-69 lat powinno zostać poprzedzone informacyjną rozmową i wspólną, świadomą decyzją, uwzględniającą potencjalne zyski i straty oraz wartości i preferencje.

Narodowy Instytut Raka USA (National Cancer Institute) niezmiennie stoi na stanowisku, że „nie ma standardowego ani rutynowego testu skriningowego dla raka stercza."

Stanowiska są jednoznaczne. Nikt (!!!) nie zaleca masowego skriningu opartego na PSA, natomiast mężczyźni zainteresowani tym testem powinni zostać poinformowani o ryzyku powikłań i niewielkim prawdopodobieństwie zysku. Powinni także zostać poinformowani, że większość wykrytych tak raków nie ma wpływu na przeżycia i nie jest leczona. Decyzja o teście PSA powinna być świadoma. Można nawet użyć stwierdzenia, że badanie PSA powinno być wykonywane na „świadome żądanie”.

\section{Co dalej $z$ badaniami PSA?}

Trzeba mieć świadomość, że strach przed rakiem stercza i głębokie zakorzenienie się testu PSA w społeczeństwie, w tym wśród części lekarzy, nie spowoduje szybkiej rezygnacji z jego stosowania. Obniżenie umieralności na raka stercza w wielu krajach wskazuje przy tym, że w jakimś stopniu jest to działalność skuteczna. Problemem jest nadrozpoznawalność nieistotnych biologicznie nowotworów i powikłania terapii, często niepotrzebnych i nadmiernych.

Problemem jest także utrwalona świadomość społeczna, że medycyna zawsze pomaga. Także lekarze nie zawsze kojarzą późniejsze zdarzenia medyczne z własną działalnością. Wyniki ERSPC wskazują, że duża grupa poważnych powikłań jest wynikiem leczenia hormonalnego, co w praktyce klinicznej jest często minimalizowane i nie jest łączone $z$ terapią.

Dalsza obserwacja ERSPC może przynieść zmiany w dotychczasowych wynikach. Po 14-15 latach obserwacji może pojawić się niewielka zmiana zarówno w umieralności na raka stercza, jak i w umieralności ogólnej. Także wskaźniki powikłań mogą ulec modulacji. Nie powinny być to jednak zmiany duże I zaskakujące.

Trwają zatem poszukiwania wyjścia z obecnego stanu niepewności co do wczesnego wykrywania raka stercza. Można tu wyróżnić dwa obozy: pierwszy (NCl, USPSTF), niezalecający w ogóle wykonywania testu PSA i czekający na inny test, drugi — głównie skupiający urologów — zmierzający przede wszystkim do redukcji powikłań i niepotrzebnego leczenia u osób z dodatnim testem PSA. Ten drugi obóz wsparty jest także „popytem” mężczyzn chcących wykonać test PSA, a także działaniami polityków i firm farmaceutycznych organizujących takie badania dla określonych zysków.

Dwie proponowane metody obniżenia częstości ryzyka to mniejsza częstość wykonywania badań PSA i stosowanie kalkulatora ryzyka. AUA proponuje, aby badanie PSA robić co dwa lata, a nawet rzadziej. Nie ma jednak badań, które jednoznacznie wskazywałyby, że takie postępowanie spowoduje znaczne obniżenie ryzyka powikłań. W badaniu ERSPC badanie wykonywano co 4 lata, więc zachowano tu dość znaczne przerwy, a mimo to wykazano dużą liczbę zdarzeń niepożądanych.

Kalkulator ryzyka to algorytm, który ma określać wskazania do biopsji u osób z wykonanym testem PSA. Poza stężeniem PSA bierze się tam pod uwagę wiek, wynik badania palcem przez odbyt, wywiad rodzinny, objętość gruczołu i wynik poprzedniej biopsji [19].

Stężenie PSA jest ważnym czynnikiem wskazującym potencjalną korzyść z terapii raka stercza. W niedawno opublikowanym badaniu PIVOT (Prostate Cancer Intervention Versus Observation Trial), gdzie w obserwacji 12-letniej nie stwierdzono istotnego wpływu wykonywania prostatektomii na obniżenie umieralności na raka stercza, taką zależność znaleziono tylko w grupie chorych z wyjściowym PSA ponad $10 \mathrm{ng} / \mathrm{ml}$ [20]. Ten wynik powinien być wzięty pod uwagę przez klinicystów.

Nie jest jasny wpływ diagnostyki i leczenia raków występujących rodzinnie na umieralność na raka stercza. Być może interwencja powinna mieć miejsce w innym momencie niż w pozostałej grupie. Wiemy z piśmiennictwa, że klasyczny skrining mammograficzny nie zmniejsza umieralności na raki piersi związane z mutacją $B R C A-1$ i podobnie może być z rakami stercza — są to biologicznie inne nowotwory, agresywne, z wczesnym rozsiewem. Nie ma badań wskazujących, jak wpływa skrining PSA i wczesna terapia w tej grupie i jakie wartości PSA są istotne. Trudno jednak w grupie takiego ryzyka zastosować randomizację.

Podobne wątpliwości można rozpisać na inne elementy kalkulatora ryzyka, nie jest zatem jednoznacznie pewne, że jego stosowanie zwiększy korzyści i zmniejszy liczbę zdarzeń niekorzystnych. Potrzebne są na to kolejne badania i lata oczekiwań na ich wyniki. Możliwe są także reanalizy kalkulatora ryzyka z już wykonanych badań randomizowanych, które jednak nie dadzą całkiem pewnych odpowiedzi.

Jeżeli chory już ma wykonaną biopsję stercza, kluczowym dla jego dalszych losów jest wskaźnik Gleasona. Ten rozbudowany i ciągle modyfikowany system był krytykowany już od jego powstania, zarówno z powodu niskiej powtarzalności, jak i nadmiernego rozbudowania.

Powtarzalność rozpoznań w systemie Gleasona pozostawia dużo do życzenia. Sam Donald Gleason miał podobno powtarzalność swoich rozpoznań na poziomie $80 \%$, co i tak wydaje się być bardzo dobrym wynikiem. Natomiast współczesna powtarzalność rozpoznań jest obliczana na 64\% dla 1 typu i 44\% dla drugiego typu [21, 22]. To bardzo mało.

W stosunkowo niedawno opublikowanej pracy zgodność rozpoznań w systemie Gleasona wyniosła $60 \%$, rosnąc do 80\% dla dychotomii „do 7 i powyżej 7" [23]. Jednak 
największe niezgodności występują w zakresie najbardziej istotnym z punktu widzenia klinicystów, to jest pomiędzy 6 a 7, czyli tam, gdzie waży się decyzja terapeutyczna. Ma to miejsce głównie w przypadku stosunkowo małej ilości utkania raka w bioptatach lub małej ilości utkania typu 4.

Te różnice w ocenie wskaźnika Gleasona mogą mieć bardzo poważne konsekwencje dla losów chorych, efektów terapii i liczby powikłań. Trzeba podkreślić, że system Gleasona jest tylko surogatem nieposiadanego przez nas narzędzia do rozróżniania raków "łagodnych" i ważnych klinicznie, a nie obiektywnym badaniem. W praktyce i tak systemowi Gleasona można przyporządkować klinicznie 3 tradycyjne stopnie złośliwości: G1 (do 6 włącznie), G2 (7, mała część utkania typu 4) i G3 (7 ze znaczną częścią utkania typu 4 oraz 8 i wyżej).

Co nas czeka w kwestii PSA i raka stercza? Wydaje się, że po ostatnich publikacjach w środkach masowego przekazu popyt na PSA nieco osłabnie — przynajmniej w USA. Będą trwały dalsze badania w zakresie kalkulatora ryzyka, modyfikacji skriningu PSA i dalsze obserwacje w badaniach kontrolowanych z randomizacją. Przede wszystkim jednak będziemy czekali na nowe testy pozwalające określić ryzyko związane z konkretnym rakiem stercza. Obiecująco wyglądają prace nad profilami genetycznymi, jednak obecnie proponowane testy, które znacząco zmniejszają liczbę biopsji i terapii, mają wspólną wadę - błędnie klasyfikują 15-20\% agresywnych raków stercza.

A co na dzisiaj? Przyłączam się do opinii, że nie ma dziś naukowych podstaw do badania PSA w normalnej bezobjawowej populacji. Jednak osoby mające przekonanie do zrobienia takiego badania po dostarczeniu jasnej informacji w tej sprawie mogą je wykonywać. Można zrozumieć mężczyzn z rodzin z dużą częstością raka stercza i trudno im odmawiać takiego badania. Jednak urolodzy zalecający PSA również powinni spojrzeć na problem z większego dystansu i dostosować postępowanie do wyników badań naukowych, aby unikać zbędnego i obarczonego dużym ryzykiem leczenia. Działania radykalne powinny być głównie ograniczane do chorych wysokiego ryzyka, z udokumentowaną naukowo korzyścią z terapii (wysokie PSA).

\section{Prof. dr hab. n. med. Radzisław Kordek}

Zakład Patologii Katedry Onkologii Uniwersytetu Medycznego $w$ Łodzi CKD/A4

ul. Pomorska 521, 92-213 Łódź

e-mail: radzisław.kordek@umed.lodz.pl

\section{Piśmiennictwo}

1. Hewitson P, Glasziou P, Irwig L i wsp. Screening for colorectal cancer using the faecal occult blood test, Hemoccult. Cochrane Database Syst Rev 2007; 1: CD001216.

2. Baum M. Harms from breast cancer screening outweight benefits if deaths caused by treatment is included. BMJ 2013; 346: 387.

3. Brodersen J, Siersma VD. Long-term psychosocial consequences of false-positive screening mammography. Ann Fam Med 2013; 11: 106-115.

4. Gøtzsche PC, Nielsen M. Screening for breast cancer with mammography. Cochrane Database Syst Rev 2009; 4: CD001877.

5. National Lung Screening Trial Research Team, Aberle DR, Adams AM i wsp. Reduced lung-cancer mortality with low-dose computed tomographic screening. N Engl J Med 2011; 365: 395-409.

6. Yin M, Bastacky S, Chandran U, Becich MJ, Dhir R. Prevalence of incidental prostate cancer in the general population: a study of healthy organ donors. J Urol 2008; 179: 892-895.

7. Schröder FH, Hugosson J, Roobol MJ i wsp. Screening and prostate-cancer mortality in a randomized European study. N Engl J Med 2009; 360: 1320-1328.

8. Thompson IM, Pauler DK, Goodman PJ i wsp. Prevalence of prostate cancer among men with a prostate-specific antigen level $<$ or $=4.0 \mathrm{ng}$ per milliliter. N Engl J Med 2004; 350: 2239-2246.

9. Thompson IM, Ankerst DP, Chi C i wsp. Operating characteristics of prostate-specific antigen in men with an initial PSA level of $3.0 \mathrm{ng} / \mathrm{ml}$ or lower. JAMA 2005; 294: 66-70.

10. Ilic D, O'Connor D, Green S, Wilt T. Screening for prostate cancer: a Cochrane systematic review. Cancer Causes Control 2007; 18: 279-285.

11. Oliver SE, May MT, Gunnell D. International trends in prostate-cancer mortality in the "PSA ERA". Int J Cancer 2001; 92: 893-898.

12. Bartsch $\mathrm{G}$, Horninger W, Klocker Hi wsp. Prostate cancer mortality after introduction of prostate-specific antigen mass screening in the Federal State of Tyrol, Austria. Urology 2001; 58: 417-424.

13. Labrie F, Candas B, Dupont A i wsp. Screening decreases prostate cancer death: first analysis of the 1988 Quebec prospective randomized controlled trial. Prostate 1999; 38: 83-91.

14. Lu-Yao G, Albertsen PC, Stanford JL i wsp. Natural experiment examining impact of aggressive screening and treatment on prostate cancer mortality in two fixed cohorts from Seattle area and Connecticut. BMJ 2002; 325: 740.

15. Andriole GL, Crawford ED, Grubb RL i wsp. Mortality results from a randomized prostate-cancer screening trial. N Engl J Med 2009; 360: 1310-1319.

16. Schröder FH, Hugosson J, Roobol MJ i wsp. Prostate-cancer mortality at 11 years of follow-up. N Engl J Med 2012; 366: 981-990.

17. Carlsson S, Sandin F, Fall K i wsp. Risk of suicide in men with low-risk prostate cancer. Eur J Cancer 2013; 49: 1588-1599.

18. Ilic D, Neuberger MM, Djulbegovic M, Dahm P. Screening for prostate cancer. Cochrane Database Syst Rev 2013; 1: CD004720.

19. van Vugt HA, Kranse R, Steyerberg EW i wsp. Prospective validation of a risk calculator which calculates the probability of a positive prostate biopsy in a contemporary clinical cohort. Eur J Cancer 2012; 48: 1809-1815.

20. Wilt TJ, Brawer MK, Jones KM i wsp. Radical prostatectomy versus observation for localized prostate cancer. N Engl J Med 2012; 367: 203-213.

21. Gleason DF. Histologic grading of prostate cancer: a perspective. Hum Pathol 1992; 23: 273-279.

22. Mostofi FK, Sesterhenn IA, Davis CJ. Prostatic carcinoma: problems in the interpretation of prostatic biopsies. Hum Pathol 1992; 23: 223-241.

23. Coard KC, Freeman VL. Gleason grading of prostate cancer: level of concordance between pathologists at the University Hospital of the West Indies. Am J Clin Pathol 2004; 122: 373-376. 